\title{
RAINFALL DERIVATIVES AS A RISK MANAGEMENT TOOL FOR GRAIN PRODUCERS: DAILY MODEL VS. INDEX MODEL
}

\author{
Ewa Broszkiewicz-Suwaj ${ }^{\bowtie}$, Leszek Kuchar \\ Department of Mathematics, The Faculty of Environmental Engineering and Geodesy, Wroclaw University of Environmental \\ and Life Sciences, ul. C.K. Norwida 25, 50-375 Wrocław
}

\begin{abstract}
Aim of the study

The first weather derivatives appeared in 1996. Soon later such instruments began to be traded on the CME (Chicago Mercantile Exchange). The group of underlyings included indices related to temperature as well as the amount of precipitation. But the specificity of weather derivatives led to the commodity exchanges stopping trade in some of them. However, climate change is increasing the risk associated with adverse weather conditions. The grain producers' sector is highly exposed to this risk, which is why the subject of this work is to build a strategy to protect against the risk of low rainfall during the growing season of plants.
\end{abstract}

\begin{abstract}
Material and methods
The valuation of rainfall derivatives is made using Monte Carlo simulation for two types of models: a model based on daily rainfall value simulation and a model based on direct estimation of the index distribution. Then these instruments are used to build a hedging strategy against the risk of low yields in the Lower Silesian District. In the last step, the effectiveness of such a strategy is examined using percentage reduction in volatility of a secured portfolio and average squared loss.
\end{abstract}

\section{Results and conclusions}

Based on the calculations, we can conclude that the amount of precipitation is an important factor affecting the level of cereal yield. Therefore, it is reasonable for grain producers to apply hedging strategies against low rainfall. Additionally we derived that daily precipitation model used in the work underestimates the derivative instrument price, whereas the model based on direct simulation of the index produces acceptable results.

Keywords: weather derivatives, hedging, rainfall index, precipitation simulation

\section{INTRODUCTION}

The risk associated with adverse weather conditions has a very large impact on the revenues of entities involved in agricultural production (Kuchar, 1989). Drought during the vegetation period of plants can significantly reduce the volume of crops, and thus affect the financial situation of grain producers. To mitigate the risk of adverse rainfall, we can consider hedging position by purchasing weather derivatives. These in- struments are available on the OTC market and can significantly change the risk profile of agricultural producers. The aim of this article is to build a strategy to protect against the risk of low rainfall during the growing season of plants. In this work, we deal with the valuation of derivatives whose underlying instrument is the index describing the cumulative amount of precipitation in a specific period of time. Next, we examine the effectiveness of hedging strategy against the risk associated with the amount of precipitation

凶e-mail: ewa.broszkiewicz-suwaj@upwu.edu.pl 
by building a portfolio containing rainfall derivatives. The valuation of weather derivatives was the subject of numerous research papers (Alaton et al., 2002; Cao and Wei, 1999). In the present work, two models based on Monte Carlo simulations are used to valuate these instruments: a model based on simulation of the daily rainfall value (Kuchar et al., 2019) and - in the next step - determining the underlying index value, as well as a model based on direct estimation of the index distribution (Odening et al., 2007). Calculations is made for data from the Lower Silesia region. Historical data describing the amount of rainfall come from a station in Wrocław, and historical data describing the amount of yield are data for the Lower Silesia region (Statistics Poland).

The article is organized as follows. Ch apter 1 provides a brief description of the data that was used for the study. Chapter 2 contains the definition and methodology for pricing the rainfall derivatives. Chapter 3 describes two ways of determining the precipitation index distribution. Chapter 4 contains the methodology and results regarding the relationship between the precipitation index and yield. Chapter 5 contains an analysis of the hedging strategy effectiveness.

\section{DATA DESCRIPTION}

Historical data describing the amount of precipitation are daily data from 1981-2018 and they present the daily sum of precipitation [in $\mathrm{mm}$ ] on particular days for the city of Wrocław. Due to missing data on some days $(5 \%)$, individual missing data were supplemented by the average rainfall values for the same day from other years. Yield data are average annual yield values (dt / ha) for grains from 1999-2018 (Statistics Poland). In order to take into account the impact of biological and agrotechnical progress on the yield, the trend of the studied data was determined and it was removed from the analyzed series. In the first step, the log-linear trend function was fitted (Vedenov, Barnett 2004):

$$
\log \left(Y_{t}^{t r}\right)=b_{1}+b_{2}(t-1999)
$$

and in the next step the detrended yield value was calculated:

$$
Y_{t}^{d e t}=Y_{t} \cdot \frac{Y_{2018}^{t r}}{Y_{t}^{t r}}
$$
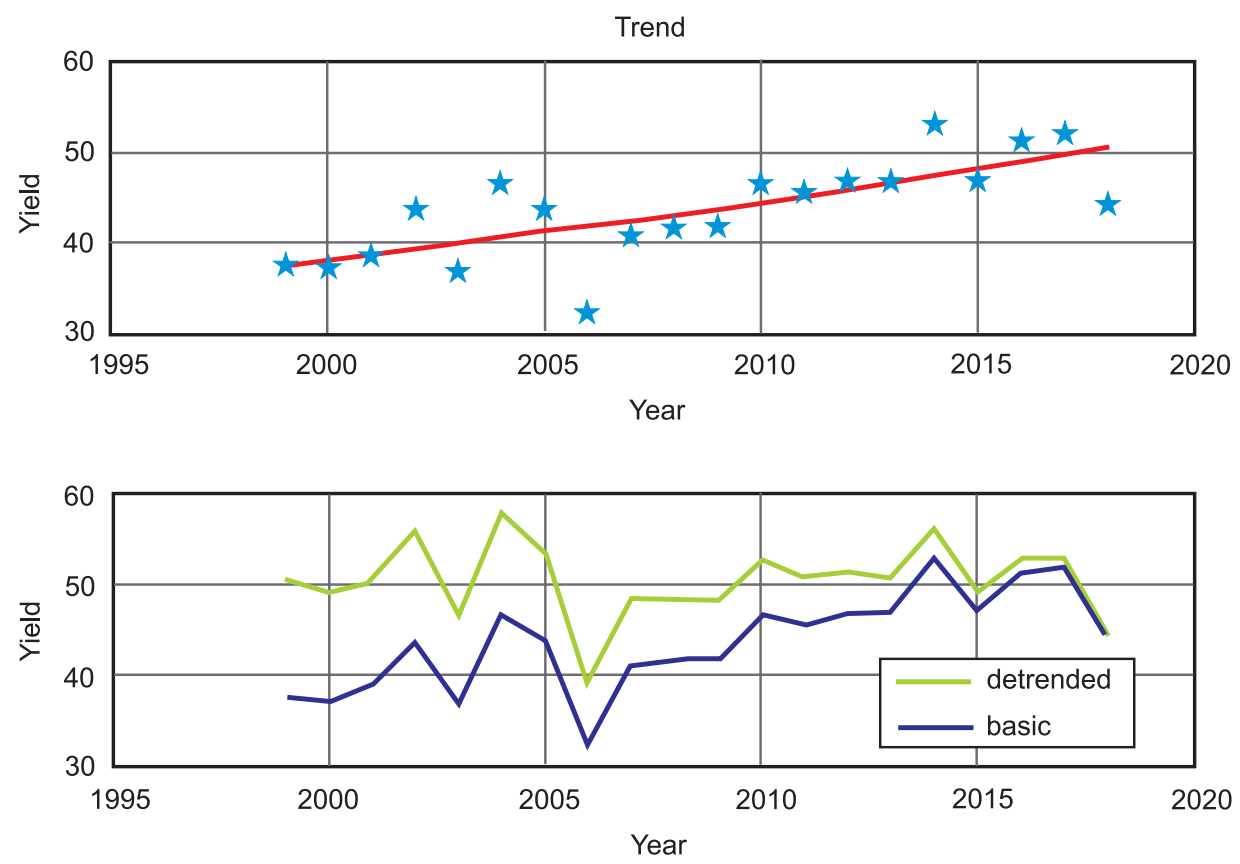

Fig. 1. The estimated trend function and plot of detrended data 
Derivative instrument pricing

As on financial markets, the price $\mathrm{F}$ of the derivative for the weather index is as follows:

$$
F=\tilde{E}(W(I)) \cdot \exp (-r T)
$$

where $\mathrm{W}$ (I) means the payout of the instrument at the $\mathrm{T}$ time of its expiration, and $\mathrm{r}$ is the risk-free interest rate. $\mathrm{E}$ is the expected $\mathrm{W}(\mathrm{I})$ value of realization, and the tilde means that the expected value is calculated assuming a risk-neutral probability. In accordance with the justification contained in the paper [Odening et al. (2007)], we assume that the risk-neutral probability is consistent with the probability for real data and we don't use the measure change mechanism.

The payout function of the derivative instrument for put option is given by:

$$
W(I)=\max (K-I, 0) \cdot V
$$

where $\mathrm{K}$ is the assumed value of the index below which we want to get paid, and $\mathrm{V}$ is the price of the difference of one index point.

In this paper we consider index I, which is the sum of precipitation in $\mathrm{mm}$ in the months from March to July inclusive:

$$
I=\sum_{i=3}^{7} x_{i}
$$

where $x_{i}$ is the sum of precipitation in the $\mathrm{i}$-th month.
For the index defined in this way, the highest degree of correlation between the index value and the yield was obtained.

\section{THE RAINFALL INDEX DISTRIBUTION}

Based on historical data of daily rainfall values in Wrocław, the distribution of I precipitation index values was simulated. In order to find the index distribution, two types of methodology were used.

- On the basis of daily data, the parameters of the daily precipitation distribution were determined, and then the index value for the scenarios obtained in this way was calculated based on the simulated daily values.

- Daily historical data has been aggregated into indices for individual years, and on this basis the parameters of the assumed probability distribution were estimated. The index values needed for valuation of the derivative are realizations of the fitted distribution.

\section{THE DAILY RAINFALL SIMULATION}

For the simulation of daily rainfall values, we used the model in which the probabilities of transition between dry and wet days are described by the first order Markov chain. Two-parameter gamma distribution is used to simulate the amount of precipitation on individu-
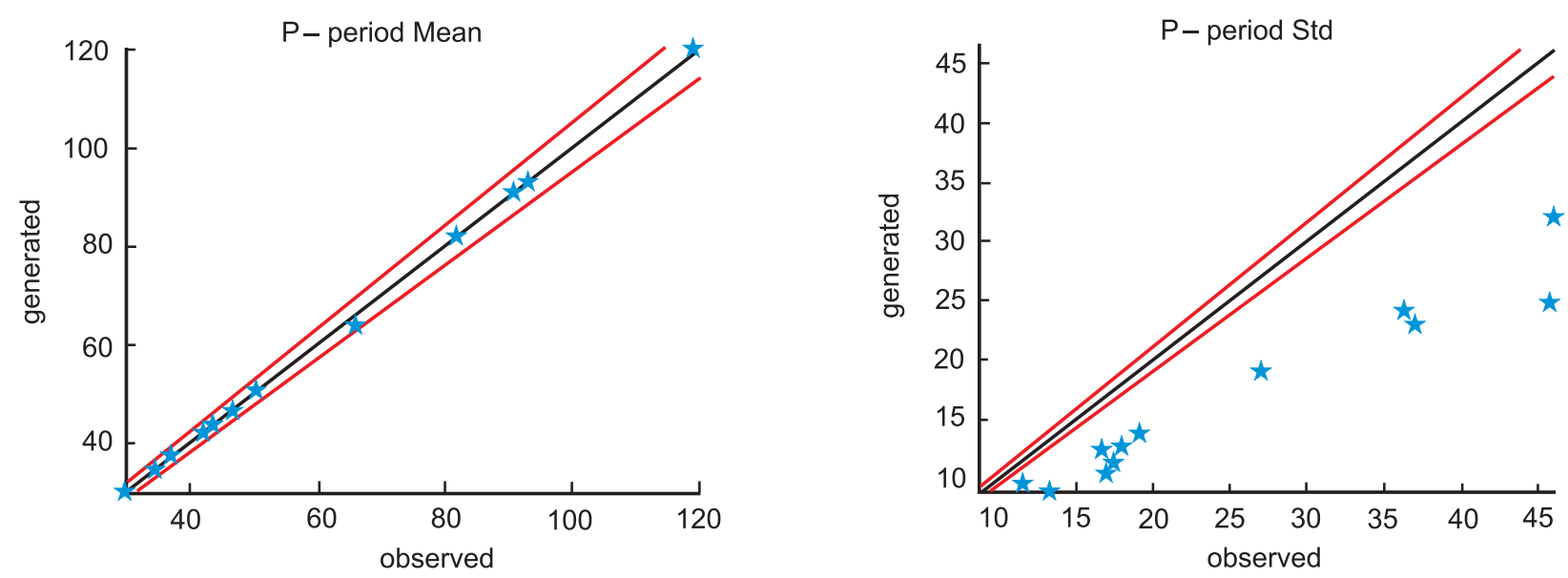

Fig. 2. Comparison of mean values for precipitation amount (left) and standard deviation (right) obtained for the observed and generated data 
al days of the month. Below are charts showing the consistency of the distribution of generated data with historical data, based on which the distribution parameters were estimated: monthly average and standard deviation.

It is worth noting that the average rainfall value in individual months of simulated data is consistent with the value for historical data, however, the standard deviation for simulated data is definitely lower than for observed data. We can quickly conclude that in simulated daily precipitation values we have fewer extreme values than in reality. 1000 iterations of daily precipitation values were generated over the year for the purpose of determining the price of the derivative.

\section{THE DIRECT INDEX DISTRIBUTION SIMULATION}

Weibull distribution (Odening et al., 2007) was used to directly simulate the index distribution. The distribution parameters have been estimated based on the index value calculated for individual years. For the purpose of determining the price of the derivative, 10.000 iterations of the cumulative index value were generated.

The above graph shows that the fitted distribution is left-skewed, which reflects well the behavior of the empirical distribution of the studied index. It follows that the risk of low rainfall is significant.

For the two types of methodology described above, the put option was priced using the Monte Carlo simulations.

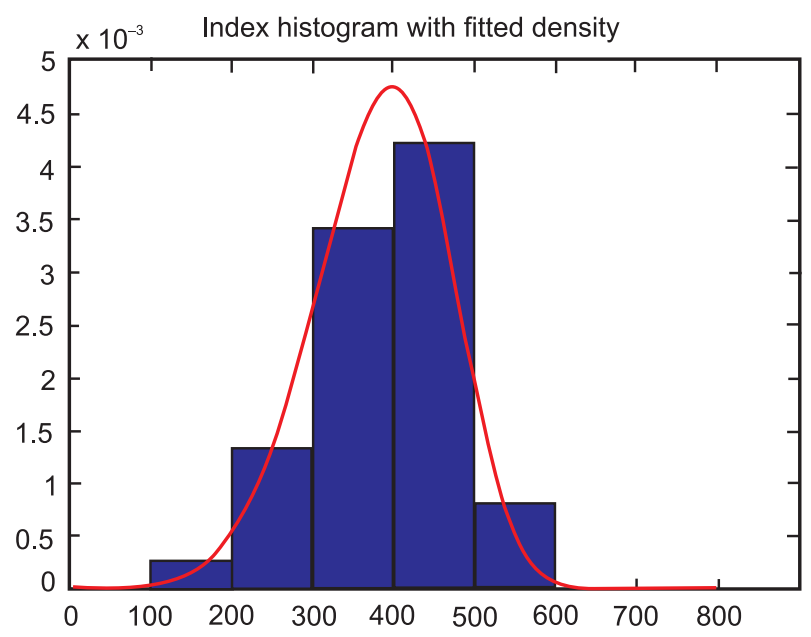

Fig. 3. Histogram of index values calculated from historical data with fitted Weibull distribution.

\section{THE CORRELATION BETWEEN RAINFALL INDEX AND YIELD ESTIMATION}

In order to examine the effectiveness of the hedging strategy based on the purchase of a rainfall derivative, in the first step it is necessary to examine how the grain yield depends on the precipitation index defined earlier.

Referring to existing studies (Zhang 2003; Kuchar 1989), a quadratic function was used to describe the relationship between grain yield and the value of the precipitation index

$$
Q\left(I_{t}\right)=a_{1}+a_{2} \cdot I_{t}+a_{3} \cdot I_{t}^{2}
$$

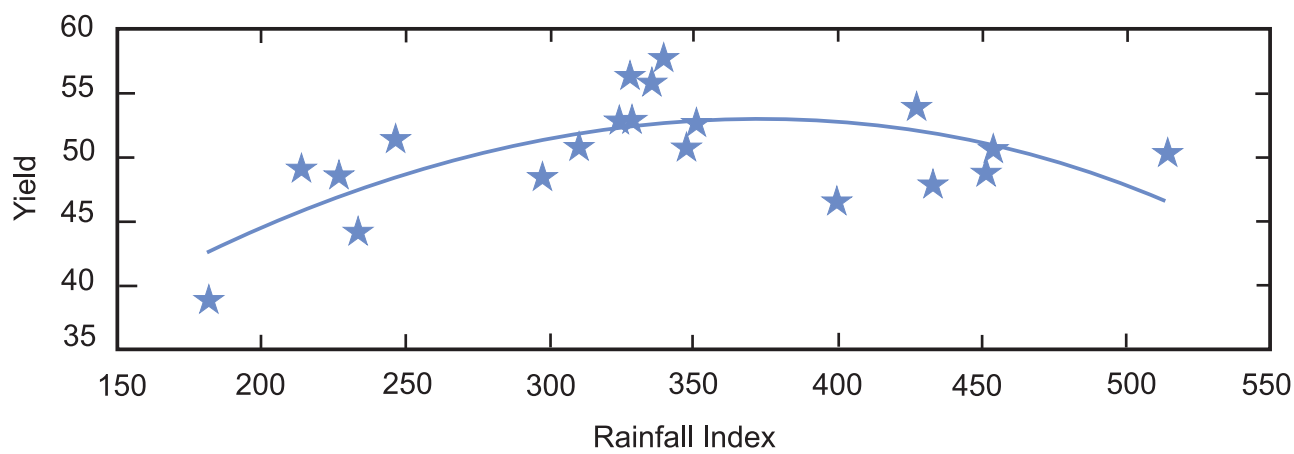

Fig. 4. Exemplary quadratic function describing the correlation between rainfall index and grain yield. 
Table 1. Fitted parameters of assumed quadratic function for different types of grain

\begin{tabular}{lcccc}
\hline Grain type & $a_{1}$ & $a_{2}$ & $a_{3}$ & $R^{2}$ \\
\hline total grains & 12.2219 & 0.2214 & -0.0003 & 0.4747 \\
\hline wheat & 19.2465 & 0.1929 & -0.0003 & 0.3588 \\
\hline rye & 14.3837 & 0.1256 & -0.0002 & 0.2760 \\
\hline barley & 14.0848 & 0.1669 & -0.0002 & 0.3598 \\
\hline oat & 11.6012 & 0.1180 & -0.0002 & 0.3700 \\
\hline
\end{tabular}

The highest $R^{2}$ was obtained for total grains. The figure below shows the total grain yield as a function of the assumed precipitation index.

\section{THE HEDGING EFFECTIVENESS ANALYSIS}

In this part of the work, we analyze the effectiveness of the strategy to protect against weather risk. We consider the put option on the precipitation index defined earlier and the impact of its purchase on the income of the entity exposed to the risk of drought during the vegetation period. To maximize the revenue from the portfolio containing such an option, we have assumed the option exercise index $\mathrm{K}=300 \mathrm{~mm}$, the price of the difference of one index point $\mathrm{V}=4 \mathrm{PLN}$ (Polish złoty), the interest rate $\mathrm{r}=1.5 \%$ and the maturity $\mathrm{T}=1$ year. For the parameters thus defined, the Monte Carlo simulation was used in order to determine the price of the put option, assuming the two analyzed models.

Table 2. The calculated put option price for two analyzed models

\begin{tabular}{cc}
\hline $\begin{array}{c}\text { Put option price }- \text { daily } \\
\text { model }\end{array}$ & $\begin{array}{c}\text { Put option price }- \text { index } \\
\text { model }\end{array}$ \\
\hline 2.4 PLN & 33.1 PLN \\
\hline
\end{tabular}

As seen in the table above, the valuation results for the two models are radically different. If we return to chapter 3, we can conclude that the low value of the option price for the daily model is associated with the low probability of occurrence of extreme values in this model (in this case, small amounts of aggregated pre- cipitation). To examine the effectiveness of the hedging strategy against drought, in the first step we define the revenue from the portfolio of the grain producer secured with the put option, and the unsecured portfolio. For a secured portfolio, this revenue is obtained from the following formula:

$$
R=(Q(I) \cdot P+W(I)) \cdot \exp (-r T)-F
$$

where $\mathrm{P}$ is the price of the product. For simplicity, this price was assumed as a fixed value at the level of $P=$ $60 \mathrm{PLN} / \mathrm{dt}$. Revenue for unsecured portfolio is calculated as:

$$
R^{\prime}=Q(I) \cdot P \cdot \exp (-r T)
$$

As a measure of effectiveness, we take the percentage reduction in volatility of a secured portfolio relative to a non-secured portfolio with the put option (Cotter and Hanly 2015)

$$
H E=1-\frac{\text { VARIANCE }}{\text { HARIged Portfolio }} .
$$

If the security completely reduces the risk $H E=1$; otherwise $H E=0$.

In addition, we examine the average squared loss for a secured and unsecured portfolio obtained from the following formulas (Vedenov and Barnett, 2004):

$$
\begin{aligned}
M R S L_{\text {without }} & =\sqrt{\frac{1}{n} \sum_{t=1}^{n}\left[\max \left(\bar{Y} \cdot P-R_{t}^{\prime}, 0\right)\right]^{2}} \\
M R S L_{\text {with }} & =\sqrt{\frac{1}{n} \sum_{t=1}^{n}\left[\max \left(\bar{Y} \cdot P-R_{t}, 0\right)\right]^{2}}
\end{aligned}
$$

where $\bar{Y}$ means long-term average yield. The lower the MRSL value, the lower the producer risk exposure.

The table below presents the results of calculations of MRSL and HE values calculated on the basis of historical yield values and corresponding precipitation index values, as well as yield values given by the square function and index values generated on the basis of the two models described earlier.

An analysis of the literature on the daily generation of precipitation data (Semenov et al., 1998; 
Table 3. Simulation of daily precipitation amount - values in PLN

\begin{tabular}{lcccccc}
\hline & \multicolumn{2}{c}{ Historical yield } & \multicolumn{3}{c}{ Yield given by quadratic function } \\
\hline Grain type & $\begin{array}{c}\text { MRSL - unsecured } \\
\text { portfolio }\end{array}$ & $\begin{array}{c}\text { MRSL-secured } \\
\text { portfolio }\end{array}$ & HE & $\begin{array}{c}\text { MRSL - unsecured } \\
\text { portfolio }\end{array}$ & $\begin{array}{c}\text { MRSL-secured } \\
\text { portfolio }\end{array}$ & HE \\
\hline total grains & 212 & 113 & $42 \%$ & 43 & 41 & $8 \%$ \\
\hline wheat & 215 & 123 & $31 \%$ & 40 & 39 & $8 \%$ \\
\hline rye & 143 & 88 & $14 \%$ & 30 & 30 & $1 \%$ \\
\hline barley & 202 & 107 & $35 \%$ & 23 & 20 & $21 \%$ \\
\hline oat & 140 & 76 & $29 \%$ & 16 & 13 & $22 \%$ \\
\hline
\end{tabular}

Table 4. Direct simulation of index value - amounts in PLN

\begin{tabular}{lcccccc}
\hline & \multicolumn{2}{c}{ Historical yield } & \multicolumn{3}{c}{ Yield given by quadratic function } \\
\hline Grain type & $\begin{array}{c}\text { MRSL }- \text { unsecured } \\
\text { portfolio }\end{array}$ & $\begin{array}{c}\text { MRSL-secured } \\
\text { portfolio }\end{array}$ & HE & $\begin{array}{c}\text { MRSL - unsecured } \\
\text { portfolio }\end{array}$ & $\begin{array}{c}\text { MRSL-secured } \\
\text { portfolio }\end{array}$ & HE \\
\hline total grains & 212 & 132 & $42 \%$ & 159 & 128 & $38 \%$ \\
\hline wheat & 215 & 139 & $31 \%$ & 142 & 116 & $37 \%$ \\
\hline rye & 143 & 104 & $14 \%$ & 96 & 88 & $10 \%$ \\
\hline barley & 202 & 125 & $35 \%$ & 118 & 73 & $62 \%$ \\
\hline oat & 140 & 92 & $29 \%$ & 82 & 50 & $57 \%$ \\
\hline
\end{tabular}

Odening et al., 2007; Kuchar, 2004) indicates that this approach underestimates the probability of low rainfall values, therefore the price of the put option for the precipitation index is understated in relation to the actual values. As a result, when analysing the effectiveness of the hedging strategy for historical yield, we get high HE values. At the same time, when analysing the yield model given by the quadratic function, due to the low probability of low rainfall coming from the daily model, the MRSL value is very low for the unsecured portfolio and almost equal to the value for the secured portfolio. The HE value is low because the option is not executed in most cases. For the model based on direct simulation of the index value, the occurrence of extreme values is more likely and hence the higher price of the option, as well as a visible significant difference in the risk of the hedged and unsecured portfolio for both the historical yield and the yield given by the quadratic function. It is worth noting that for the variant of the model directly describing the value of the index, the hedg- ing effectiveness is comparable for historical yield / rainfall and yield given by the quadratic function. The relationship between yield and precipitation index described in chapter 4 does not have a large $R^{2}$ value but gives an indicative tendency of mutual interaction between these variables. Therefore, it is very important to maintain efficiency for such a model. This efficiency is not maintained in the case of simulation of daily precipitation values, which indicates an incorrect structure of the secured portfolio.

\section{CONCLUSION}

It can be concluded from the analyses that the amount of precipitation is an important factor affecting the level of cereal yield. Therefore, it is reasonable for grain producers to apply hedging strategies against low rainfall. At the same time, it is worth noting that the daily precipitation model used in the work is not suitable for the valuation of rainfall derivatives. The model based on direct simulation of the index value works much 
better. In connection with the calculations contained in the paper, there are subsequent stages of work that should be performed. These tasks should concern further analysis of the application of daily precipitation simulation, including introduction of scaling parameters for variation (WGENK model; Kuchar, 2004), spatial precipitation generation taking into account various locations in the Lower Silesian region (Kuchar et al. 2019, Szturc et al. 2018), as well as a daily model based on higher-order Markov chains and / or precipitation set by a distribution other than the gamma distribution. We can also consider using the call option to protect against too heavy rain. In order to cover all atmospheric factors to which the agricultural producer is exposed, temperature-based derivatives may be included into the portfolio.

\section{REFERENCES}

Alaton, P., Djehiche, B., Stillberger, D., (2002). On modelling and pricing weather derivatives. Applied Mathematical Finance 9, 1-20.

Cao, M., Wei, J., (1999). Pricing weather derivative: An equilibrium approach. Rotman School of Management - Finance, 99-002.

Cotter, J.,Hanly, J. (2015). Performance of utility based hedges, Energy Economics, 49, 718-726.

Kuchar L., Broszkiewicz-Suwaj E., Iwanski S., Jelonek L. (2019). Comparison of daily flows simulated for the year 2060 on the Kaczawa River for various scenarios of climate change by simple time series analysis, E3S Web of Conferences 100.

Kuchar L. (1989): The exponential polynomial model (EPM) of yield forecasting for spring wheat based on meteorological factors and phenophase, Agric. For. Meteorol., 46(4), 339-348.

Kuchar L.(2004). Using WGENK to generate synthetic daily weather data for modelling of agricultural processes. Mathematics and Computers in Simulation 65, 69-75.

Odening M. ,Musshoff O., Xu W.(2007) Analysis of rainfall derivatives using daily precipitation models: opportunities and pitfalls, Agricultural Finance Review 67, 135-156.

Semenov M. A., Brooks R. J., Barrow E. M., Richardson W. (1998).Comparison of the WGEN and LARS-WG stochastic weather generators for diverse climates, Climate Research 10(2), 95-107.

Szturc J., Jurczyk A., Ośródka K., Wyszogrodzki A., Giszterowicz M. (2018): Precipitation estimation and nowcasting at IMGW-PIB (SEiNO system), Meteorol. Hydrol. Water Manage., 6(1), 3-12.

Woodard, J.D., Garcia, P.,(2008). Basis risk and weather hedging efectiveness. Agricultural Finance Review 68, 99-117.

Vedenov D.V., Barnett B. J. (2004). Efficiency of Weather Derivatives as Primary Crop Insurance Instruments, Journal of Agricultural and Resource Economics 29 (3), $387-403$.

Zhang H. (2003). Improving water productivity through deficit irrigation: examples from Syria, the North China Plain and Oregon, USA, IWMI Books, Reports H032649, International Water Management Institute.

\title{
DERYWATYWY POGODOWE ZWIAZANE Z OPADAMI DESZCZU JAKO NARZĘDZIE ZARZADZANIA RYZYKIEM PRODUCENTÓW ZBÓŻ: MODEL DZIENNY VS. MODEL INDEKSU
}

\begin{abstract}
ABSTRAKT
Cel pracy

Już w roku 1996 pojawiły się pierwsze pogodowe instrumenty pochodne. Niedługo potem instrumenty takie zaczęły być notowane na CME (Chicago Mercantile Exchange). W grupie instrumentów bazowych znalazły się indeksy związane z temperaturą, a także wielkością opadu. Jednakże kryzys finansowy oraz specyfika pogodowych instrumentów pochodnych spowodowały, że giełdy towarowe wycofały się z notowania części z nich. W grupie tej znalazły się instrumenty pochodne powiązane z indeksami opadowymi. Obecnie zmiany klimatu powodują, że ryzyko związane z niekorzystnymi warunkami atmosferycznymi jest coraz większe. Sektor producentów zbóż jest bardzo wyeksponowany na to ryzyko, dlatego też tematem niniejszej pracy jest zbudowanie strategii zabezpieczającej przed ryzykiem niskiej wartości opadów w okresie wegetacyjnym roślin.
\end{abstract}




\section{Materiał i metody}

Wycena opadowych instrumentów pochodnych wykonana jest przy użyciu symulacji Monte Carlo dla dwóch typów modeli: modelu symulującego dzienne wartości opadów i na tej podstawie wyznaczonego indeksu bazowego oraz modelu bezpośrednio symulującego wartość indeksu. Następnie instrumenty te użyte są do zbudowania strategii zabezpieczającej przed ryzykiem niskich plonów w województwie dolnośląskim. W ostatnim kroku zbadana jest efektywność takiej strategii poprzez analizę procenta redukcji zmienności portfela zabezpieczonego względem portfela niezabezpieczonego opcją sprzedaży oraz średniej kwadratowej straty dla zabezpieczonego i niezabezpieczonego portfela.

\section{Wyniki i wnioski}

Na podstawie przeprowadzonych obliczeń możemy stwierdzić, że ilość opadów jest ważnym czynnikiem wpływającym na poziom plonu zbóż. Dlatego zasadne jest, aby producenci zbóż stosowali strategie zabezpieczające przed niskimi opadami deszczu. Dodatkowo pokazujemy, że zastosowany w pracy model opadów dziennych niedoszacowuje ceny instrumentu pochodnego, natomiast model oparty na bezpośredniej symulacji indeksu daje zadowalające wyniki.

Słowa kluczowe: instrumenty pogodowe, startegia zabezpieczająca, indeks opadowy, symulacja opadów 